\title{
Moral Problems of the Girl- Child in Nigerian Secondary Education System \\ Okafor, Paschal Somuadina
}

\author{
School of Education \\ Federal College of Education (Technical), Umunze,Anambra State,Nigeria \\ Okafor, Regina Njideka
}

School of Sciences
Federal College of Education (Technical), Umunze, Anambra State,Nigeria

\section{Doi:10.5901/ ajis.2013.v2n10p47}

\begin{abstract}
This study investigated into moral problems of the girl child in the Nigeria Secondary education System. The study sought for the immoral acts among girl children in secondary schools, the causes, effects and strategies to control it among girl child in the secondary schools. Four research questions guided the study. The population was the secondary school teachers in the Orumba South L.G.A Anambra State who were 175. The instrument for data collection was a questionnaire. The data collected were analyzed using mean. The results of the study among others indicated that so many immoral acts exist among girl children in the secondary schools, like pilfering, truancy, gossiping, prostitution etc. Among the causes were, poor family background, peer group influence, negative use of the media. In effect many drop out of school and indulge in exam malpractices. As a control parents and teachers should be role models.
\end{abstract}

\section{Introduction}

According to the 1999 Constitution of the Federal Republic of Nigeria, a child is a person below 18 years and is disqualified for purposes of voting. The African Charter on the Right and welfare of the child defined a child to mean every human being below the age of 18 years. Under children and Young persons' Act, a child is a person under 14 years of age, while a young person is between the age of 14 and 17 years. Therefore a girl child is a female under the ages of 17 or 18 years. Among the statutory rights of this girl child is the right to education and that every obstruction that hampers their active participation should be removed.

Education according to Okafor (1992) is a process of acculturation through which the individual is helped to attain the development of his potentialities and their maximum activation when necessary, according to right reason and to achieve thereby his perfect self fulfillment. Nwabuisi (1992) sees Education as a deliberate, systematic and sustained effort to transmit, evoke or acquire knowledge, values, altitude, skills and sensibilities.

In line with this acquisition of knowledge and achievement of perfect self fulfillment, Nigeria adopted a new system of education which is the 9-3-4 system. This system implies 9 years of basic education (comprising 6 years of primary education and 3 years of junior secondary education), 3 years of senior secondary education and 4 years of university education. The girl child education is covered by 9 years Basic education and the 3 years of senior secondary education. Most primary and secondary schools are a combination of boys and girls. The aims of education in line with the various levels of education in Nigeria among others, include

- Inculcation of social norms and development of co-operation and team spirit (Pre 
.primary)

- Moulding of character and development of sound attitudes and morals in the child (Primary)

- Raising a generation of people, who can think for themselves, respect the views and feelings of others, respect the dignity of labour, appreciate those values specified under our broad national goals and live as good citizen (secondary). (Federal Republic of Nigeria (FRN), 2004)

In line with the above aims of education, rules and regulations which borders on the moral codes or ethical codes of the nation were made to govern education in Nigeria, such that the children will develop; Discipline, integrity, dignity of labour, social justices, Religious tolerance, self - reliance and patriotism.

A look at the Education sector in Nigeria, there seem to exist deviant behaviours indicating that the children find solace in maladjusted behaviours which hampers the achievement of stated educational aims and objectives. The children are influenced in most circumstance by the societal approach to moral issues Anameze [1995] observed that in the present Nigerian society, intellectual values do not seem to be insufficiently appreciated and rewarded the reason is not for fetched. One is of the opinion that money and what money can buy are preferred to academic excellence in our society.

The children including the girl child are found indulging in such immoral acts as stealing, examination misconduct, impersonation, certificate forgery, cheating, etc.

There is therefore the need to investigate into the moral problems of the girl child in the Nigerian education system.

\section{Statement of problem}

According to Ibe and Martins - Umeh (2000), the school does not exist in a vacuum. The society in which it exists has values and needs which have to be reflected by the school. Since the society tries to maintain its stability, education becomes the means through which this is achieved via the role played by teachers in their transmission of the ideal patterns of behaviour of the society to the children. This transmission role makes it possible for the maintenance and regulation of existing social order. It was in line with this that education among other things aims at raising a generation of people who can think for themselves, respect the views and feelings of others, respect the dignity of labour, appreciate those values specified under our broad national goals and live as good citizens. (FRN, 2004)

Evidences available show that deviation from the rules aimed at achieving the above aims abound among our school boys and girls today. For instance, Martins-Umeh, Assimonye, Ibe, Ezeme, and Ugwuanyi (2006) stated that in Nigeria, citizens have found solace in most of the maladjusted behaviours such as: drug addiction, disobedience, money laundrying, adulteration of drugs, impersonation, greed, godfatherism, covetousness, sexual harassment, rioting, gossiping, disrespectful, human trafficking, rituals, child abuse, bribery and corruption, alcoholism, cheating, certificate forgery, examination malpractice, etc. Igwe (1980) confirmed that without holding brief for indiscipline among our young people, what else would be expected from children who knows that their fathers are corrupt, that they amass wealth by all sorts of dubious means, that with the older generation, greed, incompetence and the philosophy of maximum gain for minimum input, seem to be our rational way of life.

The question therefore is 'what are the moral problems prevalent in our schools especially among the girl children in schools? This work therefore investigated the moral problems of the girl child in the Nigerian education system. 


\section{Purpose of Study}

The work was on the moral problems of the girl child in the Nigerian secondary education system. Specifically, the work looked at:

- The immoral acts found among secondary school girls.

- The causes of the immoral acts among secondary school girls.

- The effect of the immoral acts among secondary girls.

- The strategies to control the immoral acts among secondary school girls.

\section{Significance}

This work will be of assistance to the society, teachers and government. It will help the society to understand the implication of negative change in value system on the children. It will help the teachers to understand the moral problems among children and the possible means of controlling them. It will help the government to plan the curriculum in such a way that it will not give room to such immoral behavior.

\section{Scope}

This work was limited to the moral problems of the girl child in the Nigeria secondary education system in terms of finding out the immoral acts, the causes, effects and the strategies to control them.

\section{Research questions}

The following research questions were formulated to guide the study;

1. What are the immoral acts found among secondary school girls?

2. What are the causes of the immoral acts found among secondary school girls?

3. What are the effects of the immoral acts on the secondary school girls?

4. What are the strategies to control the immoral acts among secondary school girls?

\section{Methodology}

Survey research design was adopted in the conduct of the investigation. The study was carried out in the public secondary schools in Orumba South L.G.A of Anambra state, Nigeria. The population of the study comprised the entire teachers in the 13 public secondary schools in Orumba South L.G.A. who were 175 in number. All the 175 teachers were used as such there was no sampling. The instrument for data collection was a structured questionnaire titled "Moral Problems of the Girl child in the Nigerian Secondary Schools" (MPGNSS). The questionnaire consisted of 53 items built into four clusters (A-D) in line with the four research questions. The questionnaire response mode was in line with the researcher designed 4 point scale of Strongly Agree (SA) Agree (A) Disagree (D) and Strongly Disagree (SD). The instrument was validated by 2 experts in Measurement and Evaluation. The internal consistency of the instrument was established using Crombach Alpha where a reliability index of 0.81 was obtained.

Copies of the questionnaire were administered to the 175 teachers by the researchers and some research assistants. 175 copies were returned. Mean was used to answer the research questions. The decision rule was that any mean of 2.50 and above was accepted while any mean below 2.50 was rejected. 


\section{Results}

The results were presented in tables and analyzed according to the research questions.

\subsection{Research Question One.}

What are the immoral acts found among secondary school girls?

Table 1: Means scores of teachers on the immoral acts found among Secondary School girls.

\begin{tabular}{|c|l|c|c|c|}
\hline S/N & \multicolumn{1}{|c|}{ Item } & X & SD & Decision \\
\hline 1. & Pilfering & 3.47 & 0.73 & Accepted \\
\hline 2. & Lateness & 3.20 & 0.40 & Accepted \\
\hline 3. & Truancy & 3.40 & 0.49 & Accepted \\
\hline 4. & Abortion & 2.89 & 0.82 & Accepted \\
\hline 5. & Lesbianism & 2.61 & 1.02 & Accepted \\
\hline 6. & Prostitution & 3.00 & 0.72 & Accepted \\
\hline 7. & Disobedience & 3.40 & 0.49 & Accepted \\
\hline 8. & Bullying & 2.57 & 0.69 & Accepted \\
\hline 9. & Gossiping & 3.60 & 0.49 & Accepted \\
\hline 10. & Promiscuous & 2.71 & 0.82 & Accepted \\
\hline 11. & Insolent to elders/Disrespectful & 2.20 & 0.75 & Rejected \\
\hline 12. & Impersonation at Examination & 2.94 & 0.72 & Accepted \\
\hline 13. & Examination Misconduct & 3.40 & 0.49 & Accepted \\
\hline 14. & Indecent dressing & 3.53 & 0.59 & Accepted \\
\hline 15. & Bribery and Corruption & 1.60 & 0.49 & Rejected \\
\hline 16. & Certificate Forgery & 2.20 & 0.40 & Rejected \\
\hline 17. & Cultism & 2.42 & 0.75 & Rejected \\
\hline 18. & Alcoholism & 2.37 & 0.80 & Rejected \\
\hline 19. & Drug Abuse & 2.40 & 0.80 & Rejected \\
\hline & Grand Mean & 2.82 & 0.57 & Accepted \\
\hline
\end{tabular}

Table 1 showed that items $1,2,3,4,5,6,7,8,9,10,12,13,14$, have mean scores above 2.50 and were accepted as the immoral acts found among secondary school girls while items $11,15,16,17,18,19$ were rejected as acts not found among secondary school girls. The grand mean of 2.82 indicated that many immoral acts are found among secondary school girls

\subsection{Research Question Two}

What are the causes of immoral acts among secondary school girls?

Table 2: Mean scores of teachers on the causes of immoral acts among secondary school girls.

\begin{tabular}{|c|l|c|c|c|}
\hline S/N & \multicolumn{1}{|c|}{ Items } & X & SD & Decision \\
\hline 20 & Peer group influence & 3.40 & 0.49 & Accepted \\
\hline 21 & Poor value system in the society & 2.91 & 0.81 & Accepted \\
\hline 22 & Poor incentive and motivation of teachers & 2.34 & 0.93 & Rejected \\
\hline 23 & Laissez faire attitude of some school authorities & 2.91 & 0.81 & Accepted \\
\hline 24 & Lack of equipment /facilities in the school & 2.23 & 0.72 & Rejected \\
\hline 25 & Media promotion of pornography & 3.40 & 0.49 & Accepted \\
\hline 26 & Promiscuous life style of some parents & 3.80 & 0.40 & Accepted \\
\hline
\end{tabular}




\begin{tabular}{|c|l|c|c|c|}
\hline 27 & Over pampering of children by parents & 3.60 & 0,49 & Accepted \\
\hline 28 & Quarrelsome and broken homes & 2.97 & 0.70 & Accepted \\
\hline 29 & $\begin{array}{l}\text { Negligence of parental responsibilities as a result of } \\
\text { attachment to occupation }\end{array}$ & 3.40 & 0.49 & Accepted \\
\hline 30 & Indulgence of parents in examination malpractice & 3.80 & 0.40 & Accepted \\
\hline 31 & Proliferation of churches / doctrines & 2.23 & 0.93 & Rejected \\
\hline 32 & $\begin{array}{l}\text { Media promotion of negative values like theft , bribery } \\
\text { materialism }\end{array}$ & 3.80 & 0.40 & Accepted \\
\hline & Grand mean $x$ & 3.14 & 0.59 & Accepted \\
\hline
\end{tabular}

Table 2 showed that items 20,21,23,25,26,27,28,29,30and32 were accepted as the causes of immoral acts found among secondary school girls while items 22, 24 , and 31 were not accepted as the causes of immoral acts among the secondary school girls. The grand mean of 3.14 indicated that there were so many causes of immoral acts among secondary school girl.

\subsection{Research question three}

What are the effects of immoral acts on the secondary school girls?

Table 3: Mean scores of teachers on the effects of immoral acts on the secondary school girl.

\begin{tabular}{|c|l|c|c|c|}
\hline S/N & \multicolumn{1}{|c|}{ Items } & X & SD & Decision \\
\hline 33 & Involvement in examination misconduct & 3.40 & 0.49 & Accepted \\
\hline 34 & Indecent dressing by the girl child & 3.40 & 0.49 & Accepted \\
\hline 35 & Devoting less time for studies & 3.40 & 0.49 & Accepted \\
\hline 36 & Contacting deadly diseases like gonorreah ,HIV/AIDS & 3.23 & 0.68 & Accepted \\
\hline 37 & Poor performance in internal and external exams & 3.60 & 0.49 & Accepted \\
\hline 38 & Sorting of teachers in cash or kind to pass exams & 3.00 & 0.63 & Accepted \\
\hline 39 & Suspension /expulsion from the school & 2.80 & 0.40 & Accepted \\
\hline 40 & Drop out from school & 3.06 & 0.23 & Accepted \\
\hline 41 & Securing low quality occupation & 3.40 & 0.49 & Accepted \\
\hline 42 & Going for examination in special centers & 3.80 & 0.40 & Accepted \\
\hline & Grand mean[x] & 3.31 & 0.29 & Accepted \\
\hline
\end{tabular}

Table 3 above showed that all the items [33-42] were accepted as the effects of immoral acts on secondary school girls. The grand mean of 3.31 indicated that immoral acts have serious effects on the secondary school girls.

\subsection{Research Question Four}

What are the strategies to control immoral acts among secondary school girls?

Table 4: Mean scores of teachers on the strategies to control immoral acts among secondary school girls.

\begin{tabular}{|c|l|c|c|c|}
\hline S/N & \multicolumn{1}{|c|}{ Items } & X & SD & Decision \\
\hline 43 & Parents should be good exemplars and role models to the girl child & 3.60 & 0.49 & Accepted \\
\hline 44 & Parents should supervise the female children at home & 3.60 & 0.49 & Accepted \\
\hline 45 & $\begin{array}{l}\text { Parents especially mothers should scold and caution girl child when } \\
\text { and where necessary. }\end{array}$ & 3.80 & 0.40 & Accepted \\
\hline 46 & School authorities should not be too rigid with their rules and & 3.13 & 0.47 & Accepted \\
\hline
\end{tabular}




\begin{tabular}{|l|l|l|l|l|}
\hline & regulations & & & \\
\hline 47 & Teachers should be role models to the girl child & 3.40 & 0.49 & Accepted \\
\hline 48 & Schools should have guidance counselors & 3.80 & 0.40 & Accepted \\
\hline 49 & Moral instructions should be encouraged in schools & 3.60 & 0.49 & Accepted \\
\hline 50 & Churches should inculcate functional Christianity and not materialism & 3.40 & 0.49 & Accepted \\
\hline 51 & Parents and teachers should not encourage exam malpractice & 3.80 & 0.40 & Accepted \\
\hline 52 & Primary concern of teachers should be the welfare of the girl child & 2.49 & 0.88 & Rejected \\
\hline 53 & $\begin{array}{l}\text { Media houses to censor materials/programmers published/shown to } \\
\text { the masses }\end{array}$ & 4.00 & 0.00 & Accepted \\
\hline & Grand Mean $(x)$ & 3.51 & 0.42 & Accepted \\
\hline
\end{tabular}

Table 4 above showed that all the items except item 52 were accepted as the strategies to control immoral acts among secondary school girls. The grand mean of 3.51 indicated that there were various good strategies to control immoral acts among secondary school girl.

\section{Discussion}

Findings from the study showed that the Immoral acts among girls in the secondary schools were pilfering, lateness, truancy, abortion, lesbianism, prostitution, disobedience, bullying, gossiping, promiscuity, impersonation at the examination, examination misconduct and indecent dressing. These are ills that have bedeviled the Education system in Nigerian Society. Many Girl children in schools are so much occupied with so many unnecessary things and deviant acts that they pay less attention to education. Many of them eventually turn out to be a problem to the society.

Furthermore, the causes of the immoral acts among girls in the secondary schools were attributed to peer group influence, poor value system in the society, laissez faire attitude of some schools' authorities, media promotion of pornography, promiscuous life style of some parents, over pampering of children, quarrelsome and broken homes, negligence of parental responsibilities as a result of attachment to occupation, indulgence of parents in examination malpractice and media promotion of negative values like theft, bribery and materialism. In fact Martins- Umeh et al (2006) confirmed that immorality emanates from the society since the trend of events in the Nigerian society go to show that most citizens have found solace in most of maladjusted behaviours like drug addiction, disobedience, Money laundrying, adulteration of drugs, amassing wealth by all means, impersonation, greed, godfatherism, covetousness, sexual harassment, rioting, gossiping, disrespectful, human trafficking, rituals, child abuse, bribery and corruption, alcoholism, cheating, certificate forgery and examination malpractice. Igwe (1980) reiterated that the rush for social affluence and recognition are the prime motive or force and almost everybody's guiding star.

Other findings showed that the effect of the immoral acts on the girl child were involvement in examination malpractice, indecent dressing, devoting less time to studies, contacting deadly diseases, poor performance in examination, sorting of teachers in cash or kind to pass examination, suspension/expulsion from school, dropping out from school, securing low quality job or occupation and going for examination in special centers. This explains why some girls are known for sorting lecturers in higher institutions to gain marks. Some who could not make their WAEC end up securing very lowly paid trades or jobs.

Moreover, the strategies to control immoral act among secondary school girls are that parents and teachers should show good examples and be role models to the girl child, parents should supervise the female children at home, parents especially mothers should scold and caution their female children when and where necessary, school authorities should not be too rigid with the rules and regulations, schools should have guidance counselors, moral instruction should be encouraged in schools, parents and teachers should not encourage exam malpractice, churches should inculcate functional Christianity and not materialism, and media houses should censor materials/ programmes published or shown to the masses. These strategies are very necessary since they can 
re-direct the girl child towards nation building through inculcating trustworthiness, honesty, and the likes. Esomonu (2005) stated the rectitude of conduct, trustworthiness, honesty, purity of motive and sincerity of purpose are behaviours that can be recognized and practiced by any person for better education and national development.

\section{Recommendation}

The following recommendations were made:

1. The parents' attention should be drawn to the damage some of their behaviours bring to the children especially their negligence of their family duties. This could be done intensively through the media.

2. Government should re-enforce the national ethics of Nigeria to help correct the complete moral decay present in the society.

3. Teachers should note that their jobs are very delicate one and that they should through their duties of guidance fight the moral ills exhibited in the schools.

\section{Conclusion}

School is a social institution where the formal education of the child takes place. The aim of education cannot be achieved in the midst of immorality. But one of the findings of this study showed that immoral acts abound in the education system. There is therefore the need for the parents, teachers and government to stand up to their duties in order to eschew immorality from the education system and achieve the aims of education.

\section{References}

1999 Constitution of the Federal Republic of Nigeria.

Anameze L.N. (1995) Students guide to academic success Enugu: CPA and Gold production.

Esomonu, N. PM (2005) Moral Education: An Imperative for National Development in the 21st century. Apaper presented at the 2nd quarter colloquium of Federal College of Education (Technical), Omoku

Federal Republic of Nigeria (2004) National Policy on Education Lagos: NERDC Press

I be N.C and Martins - Umeh, N.F (2000) Sociology of Education with Elements of Social Psychology. Awka: MARPAT Educational Research and Publishers.

I gwe S.O (1980) Professional handbook for teachers. Owerri: New Africa Publishing Company Itd.

Martins - Umeh NF, Assimonye A.C, I be ,N.C, Ezeme T.S and Ugwuanyi A.A (2006) Foundation of Citizenship Education for Tertiary Institution in Nigeria. Enugu: I.N Okoro Resources Ltd.

Nwabuisi, E.M (1992) Philosophy of Nigeria Education in Modern times. Onitsha: Etukokwu Publishers (Nig.) Itd.

Okafor F.C. (1992) Philosophy of Education and Third World Perspective Enugu: Star Publishing Company 4th Ed. 
